\title{
Exploring Space in the Spirit of Kinship
}

\author{
Michelle Hanlon
}

University of Mississippi School of Law

\begin{abstract}
Clearly, it has proven difficult for the international community to agree on space governance matters. However, the nations of the world have proved unanimous support of the protection of human heritage. There is no heritage more universal than lunar landing sites on the Moon, which represent both a milestone in human evolution and development, as well as the culmination of the work of humans throughout the world and throughout history. The human relationship to space is necessarily global and universal. "The famous Earthrise image, taken by astronaut William Anders in 1968 during the Apollo 8 mission, was perhaps the most influential environmental photo ever and has taught us humility as we understand our very precious space in our solar system." Few would argue that the site where humans first set foot on another celestial body should be recognized and protected less than any site on Earth. However, presently, the extraction and sale of space resources by private companies for their own profit. Since 2015, the United States has been instigating —on a bipartisan basis-an effort to address a lacuna in international space law and assure that commercial space mining companies may retain such property rights in the minerals and elements they extract from the Moon and other celestial bodies, as to be able to sell the resources to others for their own profit. With this in mind, this article implores the international community, through COPUOS, to initiate important processes to include reaching agreements on how to protect humanity's greatest treasure in space.
\end{abstract}

Keywords: space, exploring, kinship, space resources, international space law, property rights, minerals, elements, Moon

\section{Explorando el espacio en el espíritu del parentesco}

\section{RESUMEN}

Claramente, ha resultado difícil para la comunidad internacional ponerse de acuerdo sobre cuestiones de gobernanza espacial. Sin embargo, las naciones del mundo han demostrado un apoyo uná- 
nime a la protección del patrimonio humano. Y no hay herencia más universal que los lugares de aterrizaje lunar en la Luna, que representan tanto un hito en la evolución y el desarrollo humanos, como la culminación del trabajo de los humanos en todo el mundo y a lo largo de la historia. La relación humana con el espacio es necesariamente global y universal. "La famosa imagen de Earthrise, tomada por el astronauta William Anders en 1968 durante la misión Apolo 8, fue quizás la foto ambiental más influyente de la historia y nos ha enseñado la humildad al comprender nuestro precioso espacio en nuestro sistema solar". Pocos argumentarían que el sitio donde los humanos pisaron por primera vez otro cuerpo celeste debería ser reconocido y protegido menos que cualquier sitio en la Tierra. Sin embargo, en la actualidad, la extracción y venta de recursos espaciales por parte de empresas privadas para su propio beneficio. Desde 2015, Estados Unidos ha estado instigando, de forma bipartidista, un esfuerzo para abordar una laguna en el derecho espacial internacional y asegurar que las empresas comerciales de minería espacial puedan retener dichos derechos de propiedad sobre los minerales y elementos que extraen de la Luna y otros elementos celestes. cuerpos. como poder vender los recursos a otros para su propio beneficio. Con esto en mente, este artículo implora a la comunidad internacional, a través de COPUOS, que inicie procesos importantes que incluyan el logro de acuerdos sobre cómo proteger el mayor tesoro de la humanidad en el espacio.

Palabras clave: espacio, exploración, parentesco, recursos espaciales, derecho espacial internacional, derechos de propiedad, minerales, elementos, Luna

\section{本着亲属的精神探索太空}

\section{摘要}

清晰的是, 对国际社区而言, 就太空治理事务达成一致是困 难的。不过，世界各国都对人类遗产保护表示一致支持。 并且, 没有什么遗产比月球登陆点更具有全体性, 它代表 了人类演变和发展中的里程碑, 并且是贯穿世界和历史的 人类行动顶点。人类与太空的关系必定具有全球性和全体 性。“1968年, 宇航员威廉.安德斯在执行阿波罗 8 号任务时 拍摄的著名的地球升起图像, 可能是至今最具影响力的环境 图片, 它让我们感到自身的渺小, 当我们理解自身在太阳系 中的准确位置时。” 几乎没有人会主张, 人类在另一星球 
上的首次登陆点应受到的认可和保护要比地球上的任意地点 要少。不过, 私人公司现在为一己之利而挖掘并出售太空资 源。自2015年起, 美国就开始煽动一在两党的基础上一应对 国际空间法中的空白, 并保证商业太空开采公司能保有从月 球或其他星球上挖掘的矿物质及元素的所有权, 进而能为获 取一己之利将资源出售给他人。鉴于此, 本文恳求国际社区 通过和平利用外层空间委员会 (COPUOS) 发起重要程序, 将 “就如何保护人类最伟大的空间宝藏达成一致”包括在 内。

关键词：太空，探索，亲属，太空资源，国际空间法，所有 权, 矿物质, 元素, 月球

\section{Introduction}

$\mathrm{O}$ $\mathrm{n}$ September 10, 2020, Jim Bridenstine, Administer of the United States (US) National Aeronautics and Space Administration (NASA) revealed on Twitter that the NASA "is buying lunar soil from a commercial provider!" Indeed, NASA announced that it will purchase $50 \mathrm{~g}$ to $500 \mathrm{~g}$ of lunar regolith, the equivalent of "three tablespoons to 2.5 cups," for which it "will pay between $\$ 15,000$ and $\$ 25,000 . " 2$ Hardly seems a trade to get excited about, especially when one considers that in 1993, just ".2 grams of lunar soil ... sold for $\$ 442,500 .{ }^{\prime 3}$ Moreover, this will be an "in-place" transfer, meaning it will take place on the lunar surface. ${ }^{4}$ Why the fanfare? Because this purely symbolic transaction seeks to set a controversial legal norm-namely, allowing the extraction and sale of space resources by private companies for profit. Since 2015, the United States has been instigating-on a bipartisan basis-an effort to address a lacuna in international space law and assure that commercial space mining companies may retain such property rights in the minerals and elements they extract from the Moon and other celestial bod-

1 Jim Bridenstine (@JimBridenstine), Twitter (Sep. 10, 2020, 8:31 AM, https://twitter.com/JimBridenstine/status/1304049845309669376

2 Cat Hofacker, NASA Plans to Pay Companies to Extract Tablespoons of Lunar Regolith," AeroSPACE AMERICA (Sep. 10, 2020), https://aerospaceamerica.aiaa.org/nasa-plans-to-pay-companies-to-extract-teaspoons-of-lunar-regolith/\#: :text=NASA\%20will\%20pay\%20between $\% 20$ $\% 2415 \% 2$ C000,is\%20turned $\% 20$ over\%20to\%20NASA.

3 How Much is That Vial of Moon Dust Really Worth?, TAmpa Bay Times (June 13, 2018), https:// www.tampabay.com/news/science/How-much-is-that-vial-of-moon-dust-really-worth_169133643/\#: :text=NASA\%20assessed\%20the\%20value\%20of,a\%20gram\%20in\%20today's\%20 currency.

4 Jim Bridenstine, Space Resources Are the Key to Safe and Sustainable Lunar Exploration, NASA. Gov, (Sep. 10, 2020), https://blogs.nasa.gov/bridenstine/2020/09/10/space-resources-are-the-keyto-safe-and-sustainable-lunar-exploration/. 
ies as to be able to sell the resources to others for their own profit.

International space law was born as a subset of public international law in 1963, when the United Nations General Assembly adopted a Declaration of Legal Principle Governing the Activities of States in the Exploration and Use of Outer Space. ${ }^{5}$ The Declaration captured nine important principles which were ultimately carried into the Treaty on Principles Governing the Activities of States in the Exploration and Use of Outer Space, Including the Moon and Other Celestial Bodies ${ }^{6}$ (the Outer Space Treaty), ratified in 1967. The Outer Space Treaty is often referred to as the Magna Carta of space and indeed as its name suggests, it offers only Guidelines and Principles-general "ground rules" - rather than clear and specific rules and regulations. Thus, it is not surprising that the Treaty contains many gray areas, gaps and even internal inconsistencies. Chief among the open questions is the interpretation of Article II of the Outer Space Treaty which states in full: "Outer space, including the Moon and other celestial bodies is not subject to national appropriation by claim of sovereignty, by means of use or occupation, or by any other means." While the international community largely agrees this means that no sov- ereign may make a claim to extraterrestrial territory, the question remains as to the status of resources extracted from such territory. Moreover, the provision is softened, some might say undercut, by following articles in the Treaty which indicate that States shall give "due regard" to the activities of others in space, suggesting that some sort of right is to be respected.

There remains fundamental disagreement regarding how to implement an international regime to regulate the utilization of space resources. It is without question that the decisions made today will have far-reaching implications in respect to successful and sustainable exploration and use of space. But how permissive should it be? Some would argue space is a global commons and that all resources should be shared, precluding private sale. Other, of course, take the opposite approach, arguing space resources are open and available for the taking and any regulations would hinder innovation and possible slow or halt space resource extraction projects. This article does not offer an answer. It provides a path. Rather than starting at opposite ends of the spectrum, the international community should start with a concept that has already been accepted and honored by virtually every nation on Earth: the protection of cultural her-

5 G.A. Res. 1962 (XVIII) (Dec. 13, 1963).

6 Treaty on Principles Governing the Activities of States in the Exploration and Use of Outer Space, Including the Moon and Other Celestial Bodies, Jan. 27, 1967, 18 U.S.T. 2410, 610 U.N.T.S. 205 [hereinafter Outer Space Treaty].

7 Valentina Vecchio, Customary International Law in the Outer Space Treaty, 3 German Journal of Space LaW 66, 501 (2017).

8 Outer Space Treaty, supra note 6, art. II.

$9 \quad$ Id. art. IX. 
itage. The first step to consensus is to identify sites in space that the international community can agree need special recognition and use that agreement as a baseline to establish recognizable norms to balance the non-appropriation and due regard standards imposed by the Outer Space Treaty. Part II provides a summary and review of relevant portions of international space law. Part III discusses the importance of protecting cultural heritage and draws attention to efforts implemented on Earth. Part IV briefly summarizes current debate regarding property rights and resource utilization. Part V offers a new approach to the implementation of a governance model for space and Part VI provides some concluding thoughts.

\section{The Outer Space Treaty Regime}

\section{A. The United Nations \\ Committee on the Peaceful Uses of Outer Space}

In October 1957, Sputnik 1 became the first human-made object to reach space. ${ }^{10}$ Shortly thereafter, the United Nations (UN), "[r]ecognizing the com- mon interest of [hu]mankind in outer space ... and that it is the common aim that outer space should be used for peaceful purposes [and] [w]ishing to avoid the extension of present national rivalries in this new field," ${ }^{11}$ created an ad hoc committee to, among other things, report on the "nature of legal problems which may arise in the carrying out of programmes to explore outer space." ${ }^{2}$ The Committee on the Peaceful Uses of Outer Space (COPUOS) was made a permanent body in 1959. ${ }^{13}$ COPUOS was the backdrop for negotiation and implementation the treaties which today govern space activities. Four other treaties related to sovereign space activities were negotiated in the wake of the Outer Space Treaty, colloquially known as the Rescue Agreement, ${ }^{14}$ the Liability Convention, ${ }^{15}$ the Registration Convention, ${ }^{16}$ and the Moon Agreement. ${ }^{17}$ As their names suggest, these agreements respectively offer more detailed guidance on how States should act in relation to the rescue of astronauts; responsibility and liability for damage caused by space objects; and the registration of objects launched or intended to be launched

10 Sputnik 1, NASA.Gov, https://www.nasa.gov/multimedia/imagegallery/image_feature_924.html

11 U.N.G.A. Res. 1348 (XIII) (Dec. 13, 1958).

12 Id.

13 U.N.G.A. Res. 1472 (XIV) (Dec. 12, 1959).

14 Agreement on the Rescue of Astronauts, the Return of Astronauts and the Return of Objects Launched into Outer Space, Apr. 22, 1968, 672 U.N.T.S. 119.

15 Convention on International Liability for Damage Caused by Space Objects arts. II-III, Mar. 29, 1972, 24 U.S.T. 2389, 961 U.N.T.S. 187 [hereinafter Liability Convention].

16 Convention on Registration of Objects Launched into Outer Space art. I, Jan. 14, 1975, 28 U.S.T. 695, 1023 U.N.T.S. 15.

17 Agreement Governing the Activities of States on the Moon and Other Celestial Bodies, Dec. 18, 1979, 1363 U.N.T.S. 3 [hereinafter Moon Agreement]. 
into orbit. The Moon Agreement, which suggests that States should consider developing a regulatory regime to govern lunar resource mining when such activity is likely to occur, has been ratified by only eighteen States. None of China, the U.S., or Russia has done so. And indeed, in April 2020, the US president released an Executive Order which made clear both: 1) the US unwillingness to enter into the Moon Agreement; and 2) the U.S. strategy to object to "any attempt to ... treat the Moon Agreement as reflecting or otherwise expressing customary international law."18

Negotiated during the Cold War essentially by the world's two superpowers, the four widely ratified treaties reflect a remarkable-and to date successful-détente. The overriding concern was, as the name of the COPUOS suggests, peace. As they hammered out the Magna Carta for peace in space, the negotiators cannot be faulted for not considering an environment where, as today, private entities could perform all the space activities once reserved for State actors-and very few State actors at that. As a result, peace, collaboration and freedom ${ }^{19}$ are the regime's key principles while more mundane matters, in- cluding cultural heritage preservation and private resource mining and utilization are unaddressed.

That said, the activities of private entities are not entirely overlooked. Article VI of the Outer Space Treaty makes it quite clear that States bear "international responsibility for national activities in outer space ... whether such activities are carried on by governmental agencies or by non-governmental entities." ${ }^{20}$ The Article further indicates that States must assure that all "national activities are carried out in conformity with the provisions set forth" 21 in the Treaty.

\section{B. Appropriation "By Any Other Means"}

Article II of the Outer Space Treaty indicates that "[o]uter space, including the Moon and other celestial bodies, is not subject to national appropriation by claim of sovereignty, by means of use or occupation or by any other means."22 It is a principal so embedded in the bedrock of space exploration as to be considered by many to be not just a treaty obligation but customary international law. ${ }^{23}$ However, the concept of "by any

18 Exec. Order No. 13914, 85 Fed. Reg. 20,381 (Apr. 6, 2020), https://www.govinfo.gov/content/pkg/ FR-2020-04-10/pdf/2020-07800.pdf.

19 The first Article encompasses three foundational aspects of all space activities: the exploration and use of space is the "province" of all humankind; space, including the Moon and other celestial bodies "shall be free for exploration and use by all States;" and "States shall facilitate and encourage international co-operation" in scientific investigation. Outer Space Treaty, supra note 6, art. I. Article IV avers that "the Moon and other celestial bodies shall be used ... exclusively for peaceful purposes." Id. art IV.

20 Id. art VI.

21 Id.

22 Id. art II.

23 Fabio Tronchetti, The Non-Appropriation Principle Under Attack: Using Article II of the Outer 
other means" conflicts with other provisions of the Treaty. Pursuant to Article VIII, objects left in space remain under the ownership and control of the State that put them there..$^{24}$ In fact, pursuant to Article VII of the Outer Space Treaty and Article III of the Liability Convention, States are "internationally liable" for damage caused to an object in space belonging to another State. ${ }^{25}$ Yet leaving the objects in situ, or giving them wide berth in order to avoid liability, essentially results in perpetual occupation of the surface upon which they rest. Certainly, this runs afoul of the non-appropriation principle encapsulated in Article II.

\section{Due Regard}

In addition, Article IX of the Outer Space Treaty requires all activities in outer space be conducted with "due regard" to the corresponding interests of other States ${ }^{26}$ which suggests that States should not interfere with or otherwise despoil the objects of another. But "due regard" is a standard that remains undefined. It is also used in the United $\mathrm{Na}$ tions Convention on the Law of the Sea which states that freedom of the high seas "shall be exercised by all States with due regard for the interests of the other states in their exercise of the freedom of the high seas. ${ }^{27} \mathrm{An}$ arbitral tribunal considered the meaning of "due regard" in 2015 and determined that:

the ordinary meaning of "due regard" calls for the [first State] to have such regard for the rights of [the second State] as is called for by the circumstances and by the nature of those rights. The Tribunal declines to find in this formulation any universal rule of conduct. The Convention does not impose a uniform obligation to avoid any impairment of [the second State's] rights; nor does it uniformly permit the [first State] to proceed as it wishes, merely noting such rights. Rather, the extent of the regard required by the Convention will depend upon the nature of the rights held by [the second State], their importance, the extent of the anticipated impairment, the nature and importance of the activities contemplated by the [first State], and the availability of alternative approaches. ${ }^{28}$ (emphasis added)

Space Treaty in Its Defence, 50 Proc. L. Outer SpaCe 526, 530 (2007).

24 Outer Space Treaty, supra note 6, art. VIII.

25 Id. art. VII. Liability Convention, supra note 15, art. III. To compound matters, both the Outer Space Treaty and Liability Convention liability is not based on ownership of the object, but on status as a so-called "launching state." Per the treaty regime, any one of four States may be considered a "launching State" for liability purposes: 1) the State which launches; 2) the State which procured the launch; 3) the State from whose territory the object was launched; and 4) the State from whose facility the object was launched. Liability Convention, supra note 15 , art. I.

Id. art. IX.

27 United Nations Convention on the Law of the Sea art. 87(2), Dec. 10, 1982, 3 U.N.T.S 1833.

28 The Chagos Marine Protected Area Arbitration (Mauritius v. U.K.), Case No. 2011-03, Award, 
Under this interpretation, "due regard" requires a balancing test, taking into consideration the rights of the State that have been impinged by the contested activity, the extent of the impairment, the nature and importance of the contested activity, and the availability of alternative approaches. This balance will produce different outcomes on a case-by-case basis, an uncertainty which in and of itself is enough to make States and their nationals consider carefully their international obligations in respect of space activities.

There are already many objects on the Moon, Mars and other celestial bodies-and soon to be many more. What does it mean to show those objects "due regard?" Arguably, when approaching an object which is conducting scientific experiments or undertaking commercial activity, showing "due regard" would require maintaining a certain distance to assure the activity is not affected either directly or indirectly by another actor.

But what does it mean for non-operational objects? In the one extreme, they can be treated the same as operative objects and given wide-berth. But then, arguably, a State is violating Article II of the Outer Space Treaty by keeping its non-operational objects strewn about the Moon and other celestial bodies and thereby claiming territory by an "other means." On the other extreme, because the objects are non-operational, it is not possible to do harm to them, so they may be removed from their resting areas and, ostensibly, returned to their owners. But what if the object is a cultural artifact with unquestionable historic significance? Imagine if objects found at the site where Luna 2-the first human made object to impact another celestial body lies, or Mare Tranquillitatis-the site where humans took their first off-world footsteps-were removed by private entities? Even if they were returned to Russia and the U.S. respectively, scores of details that belong on the historical record would be irretrievably lost.

And what about the first bootprints ever left by humans on another celestial body? Unlike their counterparts on Earth, cultural heritage and sites in space enjoy no protection whatsoever under any law.

\section{Protecting Human Heritage}

\section{A. A Cradle of Civilization}

In April 1959, the Egyptian Minister of Culture contacted the United Nations Educational Scientific and Cultural Organization (UNESCO) ${ }^{29}$ with an "agonizing dilemma." In order to promote and accelerate industrialization and the modernization of its economy, Egypt needed to harness the power of the Nile River. ${ }^{30}$ Unfortunately, the plan to build what is now known as the Aswan High Dam would result in the creation of a

g 519 (Perm. Ct. Arb. 2015).

29 Fekri A. Hassan, The Aswan High Dam and the International Rescue Nubia Campaign, 24 The AfRican Archaeological ReV., 73, 79 (September/December 2007).

$30 \quad$ Id. at 75. 
vast lake which would assure the obliteration of 3,000 year-old temples and monuments-footprints of an ancient civilization known as Nubia. ${ }^{31}$ In October of that same year, the Sudan sent a similar plea to UNESCO. ${ }^{32}$ Neither country had the money or the capability to protect these historic sites.

The response was swift. UNESCO spearheaded a global international effort to rescue the Nubian heritage that its Director-General, Vittorino Veronese, knew humanity could not afford to lose. As Veronese himself noted,

1. It is not easy to choose between heritage and the present well-being of people.

2. Treasures of unrivalled value are entitled to universal protection.

3. The rescue operations will not just preserve something which may otherwise be lost but will, in addition, bring to light to as yet undiscovered wealth for the benefit of all. ${ }^{33}$

It became the greatest archaeological rescue operation of all time. Even as humans waged a bitterly Cold War, raced to the Moon and fought for civil rights, the call to preserve our history was not ignored. It is estimated that US\$80 million was raised from 47
UNESCO-member nations and a number of private entities from around the globe. ${ }^{34}$ International panels of experts from five continents convened to develop and then implement strategies to save 23 temples and architectural complexes-some of them relocated brick by brick. ${ }^{35}$ In short, the international community came together to save treasures they recognized belonged, not just to Egypt or the Sudan, but to humanity as a whole.

In the words of UNESCO Director-General Amadou-Mahter M'Bow, the International Rescue Nubia Campaign "will be numbered among the few major attempts made in our lifetime by the nations to assume their common responsibility towards the past so as to move forward in a spirit of brotherhood towards the future." 36

\section{B. The World Heritage Convention Protects Outstanding Universal Value}

The success of the Nubia Campaign spawned other campaigns to save monuments of universal value including, among others, Venice and its Lagoon in Italy, the Archaeological Ruins of Moenjodaro in Pakistan and the Borobodur Temple Compounds in Indonesia. ${ }^{37}$ More important, the Nubia Campaign created the foundation for

\footnotetext{
31 Veronese, supra note 11.

32 Hassan, supra note 12 at 82.

33 Id. at 80.

34 Id. at 83-4.

35 Id. at 84.

36 Amadou-Mahtar M’Bow, A Single, Universal Heritage, The UNESCO Courier, 4 (March 1980).

37 Hasan, supra note 12 at 89.
} 
an international convention on world heritage-a convention that builds and strengthens what the Honorable Russell E. Train, who has been called a "founding father of the World Heritage Convention," 38 identified as "a sense of kinship with one another as part of a single, global community." ${ }^{\prime 39}$ Formally titled the Convention Concerning the Protection of the World Cultural and Natural Heritage, ${ }^{40}$ the Convention was adopted on November 16, 1972. With 194 States Parties, it ranks as one of the most-ratified international treaties. ${ }^{41}$ That means nearly every nation on Earth agrees "that deterioration or disappearance of any item of the cultural or natural heritage constitutes a harmful impoverishment of the heritage of all the nations of the world .... ${ }^{42}$ and that collective effort must be undertaken to protect cultural heritage of "outstanding universal value." ${ }^{43}$

The World Heritage Convention defines cultural heritage as, among other things, "works of [hu]man or the combined works of nature and[hu]man, and areas including archaeological sites which are of outstanding universal value from the historical, aesthetic, ethnological or anthropological point of view." ${ }^{44}$ Outstanding universal value is further defined as having significance "which is so exceptional as to transcend national boundaries and to be of common importance for present and future generations of all humanity. As such, the permanent protection of this heritage is of the highest importance to the international community as a whole." ${ }^{45}$

The Operational Guidelines for the Implementation of the World Heritage Convention ${ }^{46}$ (Heritage Guidelines) provide even more specific guidance. In order to be considered to have Outstanding Universal Value, the site or property must meet on or more of ten specific criteria including:

(i) represent a masterpiece of human creative genius

(ii) exhibit an important interchange of human values, over a span of time or within a

38 The Director-General Pays Tribute to Leading US Conservationist and One of the Fathers of the World Heritage Convention, UNESCO.org, https://whc.unesco.org/en/news/939 (last visited Aug. 30, 2020).

39 Abu Simbel: The Campaign That Revolutionized the International Approach to Safeguarding Heritage, UNESCO.ORG, HTTPS://EN.UNESCO.ORG/7OYEARS/ABU_SIMBEL_SAFEGUARDING_HERITAGE (last visited Aug. 30, 2020).

40 Convention Concerning the Protection of the World Cultural and Natural Heritage, Nov. 16, 1972, 27 U.S.T. 37, 1037 U.N.T.S. 151 [hereinafter World Heritage Convention].

41 https://whc.unesco.org/en/statesparties/

42 World Heritage Convention, supra note 40 at Preamble.

43 Id.

44 Id. art. 1.

45 Operation Guidelines for the Implementation of the World Heritage Convention, 49 (July 10, 2019).

46 Operation Guidelines for the Implementation of the World Heritage Convention, (July 10, 2019). 
cultural area of the world, on developments in architecture or technology, monumental arts, town-planning or landscape design;

(iii) bear a unique or at least exceptional testimony to a cultural tradition or to a civilization which is living or which has disappeared;

(iv) be an outstanding example of a type of building, architectural or technological ensemble or landscape which illustrates (a) significant stage(s) in human history; ... ${ }^{47}$

Moreover, the Heritage Guidelines anticipate the recognition of cultural landscapes: "[c]ultural properties [that] represent the "combined works of nature and [hu]man ... [that] are illustrative of the evolution of human society and settlement over time, under the influence of physical constraints ... ${ }^{48}$

\section{Sites of Outstanding Universal Value on the Moon?}

It is estimated that there are more than one hundred sites on the Moon that host evidence of human behavior. ${ }^{49}$ They each bear witness to humankind's ingenuity and confirm our species as "natural wanderers, the inheritors of an exploring ... bent that is deeply embedded in our evolutionary past." ${ }^{50}$ While this predisposition to explore is not unique to homo sapiens, "[w] hat makes us different from other expansionary species is our ability to adapt to new habitats through technology: We invent tools and devices that enable us to spread into areas for which we are not biologically adopted." ${ }^{51}$

Dirk Spanneman suggests that we should "sketch human evolution as a sequence of key psychological and technological developments." ${ }^{2}$ Of course, it starts with the ability to walk on two limbs instead of four, freeing hands to craft tools and carry those tools, as well as food, from place to place. Other milestones include:

overcoming the fear of fire innate to animals and developing control of it as a tool (some 300,000 years ago): overcoming the fear of stretches of open water innate to primates (some $60,000+$ years ago); transmission of complex

$47 \quad$ Id. 977.

48 Id. 947.

49 Michelle L.D. Hanlon, Apollo 11 Brought a Message of Peace to the Moon - but Neil and Buzz Almost Forgot to Leave it Behind, The Conversation, https://theconversation.com/apollo-11-brought-amessage-of-peace-to-the-moon-but-neil-and-buzz-almost-forgot-to-leave-it-behind-112 851\#: :text=More\%20than\%20one\%20hundred\%20sites\&text=There\%20are\%20more\%20 than\%20a,experiments\%2C\%20they\%20hold\%20invaluable\%20data.

50 Ben R. Finney \& Eric M. Jones, The Exploring Animal, in Interstellar Migration and the Human Experience 15, 15 (Ben R. Finney \& Eric M. Jones, eds. 1985).

51 Ben R. Finney \& Eric M. Jones, supra note 41, 15

52 Dirk H.R. Spennemann, The Eithcs of Treading on Neil Armstrong's Footprints, 20 SpaCe Policy 279,283 (2004). 
thought by means of language (some 30,000 years ago as evidenced by complex rock art); becoming cognizant of not being controlled by nature but of our own ability to control it (through domestication of animals and plants, some 9,000-12,000 years ago); and being cognisant of our ability to destroy our planet (first deployment of an atomic bomb, 1945)..$^{53}$

"Having humans leaving this planet and stepping onto Moon," Spanneman continues, "ranks among these key developments." 54

Even more, throughout our evolution, we have compounded our learning across cultures and centuries, developing and perfecting tools as they are distributed through diverse societies. ${ }^{55}$ We know this because of the cultural artifacts we have found around the globe. Take, for example, the Ishango bone, a 20,000-year-old baboon fibula recovered in what is today the Democratic Republic of the Congo. ${ }^{56}$ Originally believed to be just a tally stick, its three columns of deliberate marks running its length are now thought to indicate an understanding of various mathematical relationships and perhaps "the first tool upon which some logic reasoning seems to have been done." ${ }^{57}$ Humans would not have made it to be Moon without math.

Similarly, while little is known about the first attempts to make glass, it is generally believed that glassmaking was discovered 4,000 years ago, or more, in Mesopotamia. ${ }^{58}$ Glass is not only used in arts but also lenses and optics. It is crucial for observational astronomy, not to mention windows and spacesuit helmets. In short, spaceflight, whether originating in the United States, Russia, China, Japan or any other one of the handful of nations that are truly spacefaring, would not have occurred without the earliest innovations of our common ancestors, and the curious intellect of stargazers with names like Galileo, Copernicus, Ibn al-Haytham. Friedrich George Wilhelm Struve and countless others whose names have been forgotten by time.

Surely, every landing site on the Moon-soft or otherwise-is a memorial to centuries of human perseverance and ingenuity. They are unique expressions of the cumulative nature of science

\section{Id.}

54 Id.

55 The author would like to thank Dr. Marlene Losier for sharing her as yet unpublished research on heritage segmentation and human activity on the Moon. Both of the examples mentioned in the text originated with her analysis. The results of her work will be available through the website forallmoonkind.org in 2021.

56 Ross Pomeroy, Is the 20,000-Year-Old Ishango Bone the Earliest Evidence of Logical Reasoning?, RealClearScience (Nov. 23, 2015), https://www.realclearscience.com/blog/2015/11/the_earli est_evidence_of_logical_reasoning.html

57 Id., quoting Vladimir Pletser of the European Space Research and Technology Centre.

58 History OF GLAss, http://www.historyofglass.com/ 
and engineering. Each deserves consideration as exhibiting "outstanding universal value." To a one they "represent a masterpiece of human creative genius ... exhibit an important interchange of human values over a span of time ... bear a unique testimony to a civilization [ours] which is living ... and [are] an outstanding example of a ... technological ensemble or landscape which illustrates (a) significant stage[] in human history." 59

Of course, humanity's greatest technologicalachievement-putting not just one, but twelve of our own on the Moon and bringing them home safely-are memorialized on the lunar surface where six Apollo missions left behind everything from lunar modules to scientific experiments to mementos, both globally symbolic and personal. For example, Apollo 11 astronauts Neil Armstrong and Buzz Aldrin left a golden olive branch and a tiny disc containing messages of peace from 94 nations; Apollo 16 astronaut Charlie Duke, left a photo of his family. The Apollo sites are a veritable treasure trove of insight into human culture, ingenuity, evolution and society.
Archaeologists tell us that "the Apollo landing sites are not only significant because of their importance to scientific achievement but also because they are the only sited in human history that have sat frozen in time."60 Indeed: the "lack of atmospheric conditions on the Moon [have] created ... almost perfectly preserved site[s] because [they have] dealt with little interference since" humans last left the Moon in 1972." 61

Comparable sites on Earth are well-recognized and protected. In Laetoli, Tanzania, a trail of about 70 footprints, believed to be the oldest footprints of early bipedal humans are recognized as part of the Ngorongro Conservation Area as a World Heritage site, ${ }^{62}$ having "outstanding universal value." In the Vézère Valley in France, Lascaux cave is among a network of caves preserved because, among other things, it showcases drawings made by our prehistoric ancestors. ${ }^{63}$ In total, there are currently 1121 properties spread over 167 nations that are recognized on the World Heritage List. ${ }^{64}$

59 Operation Guidelines for the Implementation of the World Heritage Convention, 977 (July 10, 2019).

60 Joseph Reynolds, Legal Implications of Protecting Historic Sites in Space, in Archaeology And Heritage of the Human Movement into Space 111, 112 (Beth Laura O’Leary \& P.J. Capelotti, eds. 2015).

61 Joseph Reynolds, Legal Implications of Protecting Historic Sites in Space, in Archaeology AND Heritage of the Human Movement into Space 111, 112 (Beth Laura O’Leary \& P.J. Capelotti, eds. 2015).

62 United Nations Educational, Scientific and Cultural Organization, Ngorongoro Conservation Area, https://whc.unesco.org/en/list/39/

63 United Nations Educational, Scientific and Cultural Organization, Prehistoric Sites and Decorated Caves of the Vézère Valley, https://whc.unesco.org/en/list/85.

64 United Nations Educational, Scientific and Cultural Organization, World Heritage List, https://whc.unesco.org/en/list/. 
It is noteworthy that recognition and protection, pursuant to the World Heritage List, does not operate in a vacuum. Indeed, as noted, the genesis of the World Heritage concept was found in the need to balance the development of Egypt with the protection of Nubian heritage. Thus, in every case "there is need to have a holistic approach in order to retain the outstanding universal values of the property while addressing the needs of communities from conceptual processes to operationalization." 65

In short, protecting human history in space is not anti-development. Indeed, a by-product of such protection will be to lay the foundation for the certainty entities need to move forward in the development of a thriving space economy.

Though the process by which a site is designated World Heritage is not perfect, it is rigorous. A State must prepare a nomination file which. In the case of cultural heritage, is evaluated by the International Council on Monuments and Sites (ICOMOS). Once nominated and positively evaluated it is sent to the World Heritage Committee which meets once a year to decide which sites will be inscribed on the World Heritage List. ${ }^{66}$ Unfortunately for heritage sites located in space, a nominated property must occur "on the territory of a single State Party, or ... on the territory of all concerned States Parties having adjacent borders." ${ }^{67}$ As discussed above, the terms of the Outer Space Treaty preclude the possibility of nomination through this process as Article II specifically prohibits territorial claims by any State in space. And so we cannot apply the World Heritage Convention to sites in space.

\section{Of Safety Zones and Related Measures}

While NASA is willing to pay for Moon dust in an effort to support commercial space resource utilization, that does not address the tension between non-appropriation and due regard. In addressing this dichotomy in the Outer Space Treaty, nongovernmental organizations, lawyers and policymakers have suggested the implementation of so-called safety zones. The Hague International Space Resources Governance Working Group, ${ }^{68}$ (Hague Working Group) in

65 World Heritage Committee, 43rd Session, Item 7 of the Provisional Agenda, 35 (June 30-July 10, 2019). It is also worth mentioning that designation as a World Heritage Site also can benefit the local economy through increased tourism. While this author believes that lunar tourism will become quite popular in the future, this article will not address the benefits of tourism as the cost alone will prohibit mass tourism. Ultimately, another reason to recognize or protect certain landing sites is to assure that they are not plundered by the very wealthy few so that one day, anyone may be able to draw inspiration from the sites of these incredible achievements.

66 Operation Guidelines for the Implementation of the World Heritage Convention, g9 120-168 (July 10, 2019).

67 Id. at 134.

68 "The Hague International Space Resources Governance Working Group was established in 2016 with the purpose to assess the need for a governance framework on space resources and to lay the groundwork for such framework." https:/www.universiteitleiden.nl/en/law/institute-of-publiclaw/institute-of-air-space-law/the-hague-space-resources-governance-working-group. 
particular, urges the implementation of an international framework that would

permit States and international organizations responsible for space resource activities to establish a safety zone, or other area based safety measure, around an area identified for a space resource activity as necessary to assure safety and to avoid any harmful interference with that space resource activity. Such safety measure shall not impede the free access, in accordance with international law, to any area of outer space by personnel, vehicles and equipment of another operator. In accordance with the area-based safety measure, a State or international organization may restrict access for a limited period of time, provided that timely public notice has been given setting out the reasons for such restriction. ${ }^{69}$

The United States government also appears ready to endorse the concept of safety zones. In disseminating "principles" to guide the execution of bilateral agreements regarding space activities, the U.S. indicated that "deconfliction of activities" is a key goal. ${ }^{70}$
To support this goal, the U.S.

and partner nations will provide public information regarding the location and general nature of operations which will inform the scale and scope of 'Safety Zones.' Notification and coordination between partner nations to respect such safety zones will prevent harmful interference, implementing Article IX of the Outer Space Treaty and reinforcing the principle of due regard. ${ }^{71}$

There can be no doubt that safety zones are not only a good idea, but a necessity arguably mandated by the due regard provision of the Outer Space Treaty. However, there is not clear path to implementation of such zones. The Hague Working Group urges the development of an international framework, a move, the international aspect of which is clearly supported by the Outer Space Institute and a multitude of "distinguished signatories" from around the world who "urge States to present for adoption at the United Nations General Assembly, a resolution which would request UNCOPUOS to negotiate, with all deliberate speed, a draft multilateral agreement on space resource exploration, exploitation and utilization for consideration by the

Members included "major stakeholders from government, industry, universities, civil society and research centres." Id.

69 Building Blocks For The Development Of An International Framework On Space ReSOURCE ACtivities, g11.3 (2019), https://www.universiteitleiden.nl/binaries/content/assets/ rechtsgeleerdheid/instituut-voor-publiekrecht/lucht--en-ruimterecht/space-resources/bb-thissrwg--.

70 The Artemis Accords, NASA, https://www.nasa.gov/specials/artemis-accords/index.html\#: :text= International\%20space $\% 20$ agencies $\% 20$ that $\% 20$ join, which $\% 20$ facilitates $\% 20$ exploration $\% 2 \mathrm{C} \% 20$ science $\% 2 \mathrm{C} \% 20$ and (last visited Sep. 7, 2020).

71 Id. 
General Assembly." ${ }^{22}$ The U.S. is adopting a bilateral approach, some would argue they seek to force agreement with the safety zone concept, and its accompanying understanding that entities may stake a claim on the Moon, by dangling the opportunity "to join in America's Moon mission." 73

Underlying the differing approaches to implementation of safety zones is the U.S. disavowal of the concept that space is a global commons. This sentiment was first captured in the Commercial Space Launch Competitiveness $A c t,{ }^{74}$ signed into law by President Obama, that recognizes commercial properly rights in resources extracted from celestial bodies. The Trump Administration punctuated this statement with the 2020 issuance of an Executive Order which makes quite clear that "the United States does not view [outer space] as a global commons," but as a "legally and physically unique domain of human activity." ${ }^{75}$ Moreover, it is incontrovertible that while the Moon Agreement, ratified by only eighteen States, avers that the Moon "and its natural resources are the common her- itage of [hu]mankind"76 the much more popular Outer Space Treaty states that "the exploration and use of outer space ... shall be the province of all [hu]mankind." ${ }^{77}$ Many scholarly articles have been written that explore the concept of a global commons ${ }^{78}$ and the difference between "common heritage" and "province." Ultimately, the terms have many connotations, but like the concept of due regard itself, they provide little guidance regarding space resource utilization activity.

Implementing a safety zone regime in space would remove many of the uncertainties in the Outer Space Treaty and eliminate the guesswork in the balancing act presupposed by the concept of due regard. However, the fact is that a bilateral approach, as espoused by the U.S. feels exclusive and, if does not garner widespread adoption, it will leave many sites-both operable and heritage-vulnerable. Similarly, an international effort to address these important issues through the COPUOS will undoubtedly take many years, if not decades to reach conclusion. ${ }^{79}$

72 http://www.outerspaceinstitute.ca/docs/InternationalOpenLetterOnSpaceMining.pdf.

73 Robert Cochetti, Who Can Own the Moon, The Hill (June 24, 2020), https://thehill.com/opin ion/technology/504289-who-can-own-the-moon.

74 U.S. Commercial Space Launch Competitiveness Act, H.R. 2262, 114 $4^{\text {th }}$ Cong. (2015).

75 Exec. Order No. 13914, 85 Fed. Reg. 70 (Apr. 10, 2020).

76 Moon Agreement, supra note 17, art. 11.

77 Outer Space Treaty, supra note 6, art. I.

78 For an excellent review of the concept, see Henry R. Hertzfeld, Brian Weeden \& Christopher D. Johnson, How Simple Terms Mislead Us: The Pitfalls of Thinking about Outer Space as a Commons, 58 Proc. Int'L Inst. Space L. 533 (2015).

79 It took nine years for delegates to the United Nations Committee on the Peaceful Uses of Outer Space to agree to twenty-one nonbinding guidelines supporting the long-term sustainability of outer space activities and the delegates have yet to agree on even the definition and delimitation of outer space-after decades of consideration. 


\section{A New Approach}

\section{A. History at Risk}

While it may be argued that we have some time before actual mining operations begin on the Moon or any other celestial body, the fact is that the concept of due regard for objects already on the lunar surface needs to be addressed on a much swifter timetable. Cultural artifacts on the Moon are vulnerable to any activity on the Moon. Indeed, the NASA recognized this in 2010 when it organized a team solely to address questions regarding the protection of historic sites on the Moon. The team developed and released its report, "NASA's Recommendations to Space-Faring Entities: How to Protect and Preserve the Historic and Scientific Value of U.S. Government Lunar Artifacts" (NASA Guidelines), in July 2011. ${ }^{80}$ The NASA Guidelines recommend the implementation of a two kilometer "exclusion radius" around significant lunar heritage sites. Per the Guidelines, no vehicle should overfly or attempt to land on the Moon within a two-kilometer radius of any so-called United States Government heritage lander, defined to include the Apollo and Surveyor lunar landing sites. ${ }^{81}$ The distance was chosen primarily to alleviate the destructive potential of the regolith ejecta effect in the lunar environment. ${ }^{82}$ Essentially, any activity that will stir the lunar surface, whether a rover or a lander, will cause the very abrasive regolith to impact any hardware within a certain radius with the potential of causing severe damage. ${ }^{83}$

These Guidelines, which are not binding or enforceable, even against US nationals, ${ }^{84}$ highlight the vulnerability of cultural heritage on the Moon, especially in the face of increased activity.

\section{B. So Put History First}

Clearly, it has proven difficult for the international community to agree on

80 NASA, NASA's Recommendations to Space-Faring Entities: How to Protect and Preserve the Historic and Scientific Value of U.S. Government Lunar Artifacts 12 (Jul. 2011), https://www.nasa.gov/ sites/default/files/617743main_NASAUSG_LUNAR_HISTORIC_SITES_RevA-508.pdf [hereinafter NASA Guidelines].

81 Id. at 7.

82 See Michelle L.D. Hanlon \& Bailey Cunningham, The Plume Effect: An "Aggravation and Frustration" That Imperils Our History and Our Future, 43 J. SpaCE LAW 309 (2019).

Research indicates that upon approach and landing, lunar lander engine exhaust will blow, rocks, soil and dust at high velocities. This lander ejecta can severely damage hardware even tens of kilometers away from the landing site. Building berms or using terrain obscuration to obstruct or curtail the ejecta each offer only partial solutions to this potentially mission-ending issue because large landers can send ejecta into high trajectories that cannot be successfully blocked. Indeed, it has been shown that it is even possible for ejecta to damage or destroy spacecraft orbiting the Moon. Id. at 309 .

83 Id. at 312-313.

84 The One Small Step to Protect Human Heritage in Space Act would require entities licensed by the United States to comply with NASA's Guidelines. One Small Step Act, S. 1694, 116th Cong. (2019). The Act passed the U.S. Senate unanimously in 2019 but has yet to be considered by the U.S. House of Representatives. 
space governance matters. However, the nations of the world have proved unanimous support of the protection of human heritage. And there is no heritage more universal than lunar landing sites on the Moon, which represent both a milestone in human evolution and development as well as the culmination of the work of humans throughout the world and throughout history. The human relationship to space is necessarily global and universal. "The famous Earthrise image, taken by astronaut William Anders in 1968 during the Apollo 8 mission, was perhaps the most influential environmental photo ever and has taught us humility as we understand our very precious space in our solar system." ${ }^{85}$ More than 600 million people "tuned into watch or listen to the Apollo 11 lunar landing." ${ }^{\text {G }} \mathrm{Few}$ would argue that the site where humans first set foot on another celestial body should be recognized and protected less than any site on Earth.

With this in mind, rather than embark upon the development of an entirely new legal regime to govern space resource utilization and flesh out the specifics of due regard, the international community, through the COPUOS should initiate the important process by reaching agreement on how to protect humanity's greatest treasures in space. Starting with humanity's firsts on the Moon-Luna 2, first hard land- ing, Luna 9, first soft landing, Apollo 11, first crewed landing - the international community can consider each level of deference to be given to certain objects and sites. The COPUOS should solicit expert testimony from geologists and engineers who can describe the effects and trajectory of the plume effect. Then taking the science into consideration, agree to the establishment of safety zones, barring access to any of these sites until humans have the technology to approach them without destroying them. And, given the strong ownership structure of Article VIII of the Outer Space Treaty, any approach must be with the approval of the State that retains the ownership of the objects. These parameters will serve as the baseline, the most severe and rigorous protections any site on the Moon can enjoy. It is an ideal starting point to: 1) make the international community comfortable with the concept of safety zones; and 2) build the scientific understanding and knowledge necessary to combat both foreseen (intentional intrusion) and unforeseen (plume effect) hazards to objects on the Moon.

Beyond these three firsts, there will no doubt, be required debate over the status of other sites and objects. But these can be addressed in a manner similar to the process adopted by the World Heritage Convention. As a matter of first instance, the COPUOS

85 M. Ann Garrison Darrin, The Impact of the Space Environment on Material Remains, in ARCHAEology and Heritage of the Human Movement into Space 13, 27 (Beth Laura O'Leary \& P.J. Capelotti, eds., 2015).

86 J. Reynolds, Legal Implications of Protecting Historic Sites in Space, in Archaeology and Heritage of the Human Movement into Space 13, 27 (Beth Laura O’Leary \& P.J. Capelotti, eds., 2015). 
must agree to a definitive list and location of all the sites and objects on the Moon. A digital catalog of these items is maintained by the nongovernmental organization, For All Moonkind, and would be an excellent starting point. ${ }^{87}$ Once affirmed, sites and objects should be categorized. The two extreme categories would be: 1) debris or trash, available for inspection, and even recycling and reuse upon negotiation with the State which is the owner of the object; and 2) cultural heritage of universal value. The COPUOS may initiate a nomination process and invite States to nominate their object and the sites upon which they sit for consideration of universal value. Subsequent categories may include an identification of operative equipment used for scientific purposes and operative equipment used for commercial purposes. Finally, the COPUOS will need also to consider commercial property that has no purpose. For example, companies like Astrobotic are offering to take private object to rest on the Moon as part of their DHL Moonbox ${ }^{\mathrm{rm}}$ kit, ${ }^{88}$ and Celestis ${ }^{89}$ promises to take human remains to the lunar surface. What should "due regard" entail for these items? Viewing all of these sites from the prism of history will provide new perspective on all these matters.

A final benefit of approaching the task of implementing due regard through the establishment of a safety zone regime is that the entire process will be accomplished from a baseline of conservation rather than exploitation. As we have learned on Earth, development need not be halted by preservation efforts; however, humans have been given a unique gift in the 50-year gap between crewed visits to the Moon. The site of one of our own momentous evolutionary accomplishments sits pristine, waiting for our return. We will never know where our ancestors took their first bipedal footsteps, where we first harnessed fire, or where we made our first tools. But we know where exactly our first human-made object impacted the Moon, and where our first off world footsteps were taken. These sites will forever hold the remnants of our birth as a spacefaring community, the cradle of our spacefaring species.

\section{Conclusion}

It is appealing to consider this our generations Nubia moment, which the author has done in the past. ${ }^{90}$ Like Nubia, the cradle of our spacefaring future is threatened by the need for development, here the development of space resource utilization, specifically on the Moon. However, unlike Nubia, saving our history on the Moon will not cost $\$ 80$ million, nor will it require moving shrines and temples. It simply requires formalizing and oralizing a tacit un-

87 https://moonregistry.forallmoonkind.org/

88 https://www.astrobotic.com/moon-box

89 https://www.celestis.com/

90 Michelle Hanlon, Our Nubia Moment, Spacewatch.Global, https://spacewatch.global/2018/02/ spacewatchglthemes-space-archaeology-nubia-moment-michelle-hanlon/ 
derstanding that there are sites on the Moon that deserve recognition and protection for their universal value to humanity.

But this builds on the concept of heritage protection awakened by Nubia and takes it to (forgive me) new heights both literally and figuratively. As we embark on the next stage of our evolutionary development, we have the unique opportunity to manage that development with care we never considered in the past. But of even more import to the commercial space industry, opening discussion from a place of agreement-preservation of heritage-will speed the process needed to address the uncertainty inherent in the balancing proposition required by the concept of due regard. Not to mention the fact that it will help to preserve for generations to come the sites that create a seemingly bottomless well of inspiration for space entrepreneurs and dreamers.

Finally, recognizing heritage outside the norm of sovereign territory will provide one more unique and matchless gift: the chance to recognize incredible technological achievements not as national triumphs, but human triumphs. As Neil Armstrong descended the ladder of the lunar module at Tranquility Base and planted his boot in the regolith, he completed a journey that started with a human who decided to stand up on two feet. A new journey is starting for humanity, one that is truly without boundaries; one that should be explored outside the confines of our Earthly sovereign paradigms. We can take that first step now. Let this be our major attempt of our lifetime to assume common responsibility towards the past so as to move forward in the spirit of kinship to the future. 